\title{
8p23.2-pter Microdeletions: Seven New Cases Narrowing the Candidate Region and Review of the Literature
}

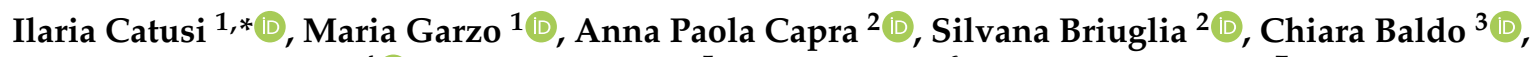 \\ Maria Paola Canevini ${ }^{4}\left(\mathbb{D}\right.$, Rachele Cantone ${ }^{5}$, Flaviana Elia ${ }^{6}$, Francesca Forzano ${ }^{7}$, Ornella Galesi ${ }^{8}$, Enrico Grosso ${ }^{5}$, \\ Michela Malacarne ${ }^{3}$, Angela Peron ${ }^{4,9,10} \oplus$, Corrado Romano ${ }^{11} \oplus$, Monica Saccani ${ }^{4} \oplus$, Lidia Larizza ${ }^{1 \oplus}$ and \\ Maria Paola Recalcati ${ }^{1}$ (1)
}

1 Istituto Auxologico Italiano, IRCCS, Laboratory of Medical Cytogenetics and Molecular Genetics, 20145 Milan, Italy; m.garzo@auxologico.it (M.G.); 1.larizza@auxologico.it (L.L.); p.recalcati@auxologico.it (M.P.R.)

2 Department of Biomedical, Dental, Morphological and Functional Imaging Sciences, University of Messina, 98100 Messina, Italy; annapaola.capra@unime.it (A.P.C.); silvana.briuglia@unime.it (S.B.)

3 UOC Laboratorio di Genetica Umana, IRCCS Istituto Giannina Gaslini, 16147 Genova, Italy; chiarabaldo@gaslini.org (C.B.); michelamalacarne@gaslini.org (M.M.)

4 Child Neuropsychiatry Unit-Epilepsy Center, Department of Health Sciences, ASST Santi Paolo e Carlo, San Paolo Hospital, Università Degli Studi di Milano, 20142 Milan, Italy; mariapaola.canevini@unimi.it (M.P.C.); angela.peron@unimi.it (A.P.); monica.saccani@asst-santipaolocarlo.it (M.S.)

5 Medical Genetics Unit, Città della Salute e della Scienza University Hospital, 10126 Turin, Italy; rachele.cantone@unito.it (R.C.); egrosso@cittadellasalute.to.it (E.G.)

check for updates

Citation: Catusi, I.; Garzo, M.; Capra, A.P.; Briuglia, S.; Baldo, C.; Canevini, M.P.; Cantone, R.; Elia, F.; Forzano, F.; Galesi, O.; et al. 8p23.2-pter Microdeletions: Seven New Cases Narrowing the Candidate Region and Review of the Literature. Genes 2021, 12, 652. https://doi.org/10.3390/ genes12050652

Academic Editor: Orazio Palumbo

Received: 18 March 2021

Accepted: 22 April 2021

Published: 27 April 2021

Publisher's Note: MDPI stays neutral with regard to jurisdictional claims in published maps and institutional affiliations.
6 Unit of Psychology, Oasi Research Institute-IRCCS, 94018 Troina, Italy; felia@oasi.en.it

7 Clinical Genetics Department, Guy's \& St Thomas' NHS Foundation Trust, London SE1 9RT, UK; Francesca.Forzano@gstt.nhs.uk

8 Laboratory of Medical Genetics, Oasi Research Institute-IRCCS, 94018 Troina, Italy; ogalesi@oasi.en.it

9 Human Pathology and Medical Genetics, ASST Santi Paolo e Carlo, San Paolo Hospital, 20142 Milan, Italy

10 Division of Medical Genetics, Department of Pediatrics, University of Utah School of Medicine, Salt Lake City, UT 84132, USA

11 Unit of Pediatrics and Medical Genetics, Oasi Research Institute-IRCCS, 94018 Troina, Italy; cromano@oasi.en.it

* Correspondence: ilaria.catusi@gmail.com

\begin{abstract}
To date only five patients with 8p23.2-pter microdeletions manifesting a mild-to-moderate cognitive impairment and/or developmental delay, dysmorphisms and neurobehavioral issues were reported. The smallest microdeletion described by Wu in 2010 suggested a critical region (CR) of $2.1 \mathrm{Mb}$ including several genes, out of which FBXO25, DLGAP2, CLN8, ARHGEF10 and MYOM2 are the main candidates. Here we present seven additional patients with 8p23.2-pter microdeletions, ranging from $71.79 \mathrm{~kb}$ to $4.55 \mathrm{Mb}$. The review of five previously reported and nine Decipher patients confirmed the association of the $\mathrm{CR}$ with a variable clinical phenotype characterized by intellectual disability/developmental delay, including language and speech delay and/or motor impairment, behavioral anomalies, autism spectrum disorder, dysmorphisms, microcephaly, fingers/toes anomalies and epilepsy. Genotype analysis allowed to narrow down the 8p23.3 candidate region which includes only DLGAP2, CLN8 and ARHGEF10 genes, accounting for the main signs of the broad clinical phenotype associated to 8p23.2-pter microdeletions. This region is more restricted compared to the previously proposed CR. Overall, our data favor the hypothesis that DLGAP2 is the actual strongest candidate for neurodevelopmental/behavioral phenotypes. Additional patients will be necessary to validate the pathogenic role of DLGAP2 and better define how the two contiguous genes, ARHGEF10 and CLN8, might contribute to the clinical phenotype.
\end{abstract}

Keywords: 8p23.2-pter microdeletion; 8p23.3; chromosomal microarray analysis (CMA); critical microdeletion region (CR); candidate region; small deletions; ARGHEF10; DLGAP2; developmental delay; behavior disorder 


\section{Introduction}

Deletions of the distal region of the short arm of chromosome 8 have been frequently reported in the literature as either isolated terminal/interstitial deletions or terminal deletions associated with more proximal duplications [1]. These rearrangements are mainly due to the architecture of the $8 \mathrm{p} 23.1$ region, characterized by the presence of two olfactory receptor gene clusters and defensin repeats, named REPD (repeat-distal) and REPP (repeat-proximal), that mediate chromosomal rearrangements through a U-type exchange mechanism [2-6].

Conversely, large deletions including the 8p23.1 region and isolated microdeletions of the more distal 8p23.2-pter region have rarely been reported in patients displaying various clinical features, including developmental delay (DD)/intellectual disability (ID), microcephaly, mildly dysmorphic features, language delay and/or behavioral problems [7]. Microdeletions of this region are hardly ever recorded in the database of genomic variants (DGV) which collects copy number variants (CNVs) in healthy control samples [8].

To date only five patients carrying 8p23.2-pter microdeletions have been characterized by chromosomal microarray (CMA) analysis in the literature and other cases have been reported in the DECIPHER database [7,9-11]. Furthermore, the smallest microdeletion described by Wu et al. in 2010 suggested a possible critical region (CR) of $2.1 \mathrm{Mb}$ in 8p23.3 $[7,11]$. The CR comprises several genes out of which the OMIM genes FBXO25, DLGAP2, CLN8, ARHGEF10 and MYOM2, most of which share a role in neural differentiation and function [12-17], are main candidates for DD/ID, microcephaly and neurobehavioral disorders.

Here we report seven new patients with interstitial microdeletions included in the 8p23.2-pter region which partially overlap with the previously mentioned CR [7,11]. Phenotypic evaluation of our patients, compared to that of five previously reported patients and additional nine obtained from the DECIPHER database, confirmed a shared clinical phenotype, mainly characterized by ID/DD, including language and speech delay and/or motor impairment, behavioral anomalies/attention deficit and hyperactive disorder (ADHD), autism spectrum disorder (ASD) and dysmorphisms. The analysis of microdeletion extensions enabled us to point out a candidate region, more restricted compared to the previously proposed $\mathrm{CR}$, and to propose a genotype-to-phenotype correlation for a few core clinical signs. Moreover, possible mechanisms accounting for the clinical variability across microdeletion carriers are herein discussed.

\section{Materials and Methods}

The seven patients described underwent standard and molecular cytogenetics analyses as routine diagnostic procedures in five different Italian Cytogenetics Laboratories. Informed consent signed by the patients' parents, adult patients themselves and healthy adult carriers was provided. Chromosome analysis was performed on peripheral blood lymphocytes using QFQ banding techniques on metaphase chromosomes obtained by standard procedures. Array based comparative genomic hybridization (array-CGH) analyses were performed using: Bluegnome $4 \times 180 \mathrm{~K}$ CytoChip Oligo ISCA, resolution $\sim 25 \mathrm{~kb}$ (Patient 1); Agilent SurePrint G3 Human CGH+SNP Microarray kit $4 \times 180 \mathrm{~K}$, resolution $\sim 25 \mathrm{~Kb}$ (Patients 2 and 7); Agilent SurePrint G3 Oligo ISCA v2.0 $4 \times 180 \mathrm{~K}$, resolution $\sim 25 \mathrm{~kb}$ (Patient 4); Agilent SurePrint G3 Human CGH Microarray kit $8 \times 60 \mathrm{~K}$, resolution $\sim 100-150 \mathrm{~kb}$ (Patients 3, 5 and 6). Nucleotide designations were assigned according to the hg19/GRCh37 assembly of the human genome. BAC-FISH (Bacterial artificial chromosome - Fluorescence in situ hybridization) experiments with the RP11-666119 BAC clone were performed according to Lichter et al. 1988 [18] with minor modifications. FISH analyses with chromosome 8 subtelomeric-specific probes (ToTelVysion, Vysis, Downers Grove, IL, USA) were performed according to manufacturer's instructions. All coding exons of the $C L N 8$ gene were analyzed by direct sequencing of polymerase chain reaction (PCR) products using standard protocols. Patients 1, 2 and 4 underwent Leiter-3, ADOS (Autism Diagnostic Observation Schedule), VABS II (Vineland Adaptive Behavior Scales-II), ABC-2 
(Movement Assessment Battery for Children 2), PEP-3 (PsychoEducational Profile 3) and ADI-R tests. Patient 5 underwent WISC-III (Wechsler Intelligence Scale for Children-III), Leiter-R and ADOS tests; Patient 7 underwent WISC-IV, Leiter-3 and CPM (Coloured Progressive Matrices) tests. In patients 3 and 6, ID and DD assessments have been performed through clinical evaluation by experienced neurologists.

Protocols provided by the companies have been followed with no modifications.

Consent for publication of research studies were obtained from all individuals.

\section{Results}

Cytogenomic and Phenotypic Characterization of Seven Novel 8p23-Pter Microdeletion Patients: Cross-Comparison to Previously Reported Patients

Our study includes seven patients, six males and one female, with age at diagnosis ranging from 2 to 38 years. CMA was performed for all seven patients and the results are provided in Figure 1 and Table 1. Of note, Patients 3, 5 and 6 have been extrapolated from a cohort of 5110 Italian patients, collected by the Cytogenetics/Cytogenomics working group of the Italian Society of Human Genetics (SIGU) and processed by CMA as reported [19]. Patients 1, 2, 4 and 7 were collected by the same SIGU working group afterwards. Patient 7 corresponds to DECIPHER patient 383055. Additional approaches used were: standard cytogenetics analysis, that for Patient 3 revealed a mosaic karyotype 45,XY,-8[8]/46,XY,r(8)(p23.2q24.3) [42], and targeted FISH analysis using the 8p subtelomeric probe and BAC probe RP11-666I19, to confirm the microdeletion in Patient 1 (data not shown). Array-CGH analysis on Patient 3 genomic DNA didn't reveal either imbalances involving $8 \mathrm{q}$ or mosaic monosomy of chromosome 8 . However, the declared detection rate of the array-CGH platform used does not guarantee to identify mosaicism under the rate of $30 \%$. Furthermore, given that the $123 \mathrm{~kb}$ deletion of Patient 6 , which involves only the CLN8 and ARHGEF10 genes, did not manifest any effect in the carrier brother, direct sequencing analysis of polymerase chain reaction (PCR) products was performed on the patient's genomic DNA in order to check if eventual unmasking of a recessive CLN8 mutation on the non-deleted allele could be responsible for the patient's phenotype. Sequence changes in CLN8 exons were ruled out (data not shown). The inheritance pattern was precluded for Patient 1, since he was adopted, but could be determined in five of the six remaining patients: the microdeletion arose de novo in Patients 3 and 4, was transmitted to Patient 2 by his apparently healthy mother and to Patient 5 by his father, which presented a milder phenotype. Moreover, we presume that the microdeletion was inherited also by Patient 6 , because his unaffected brother carried the same microdeletion (Table 1). The extent of the microdeletions ranged from the $71.79 \mathrm{~kb}$ deletion detected in Patient 4 , which contained only the DLGAP2 gene, to the $4.55 \mathrm{Mb}$ deletion of Patient 3, comprising 9 coding genes (Figure 1 and Table 1). 


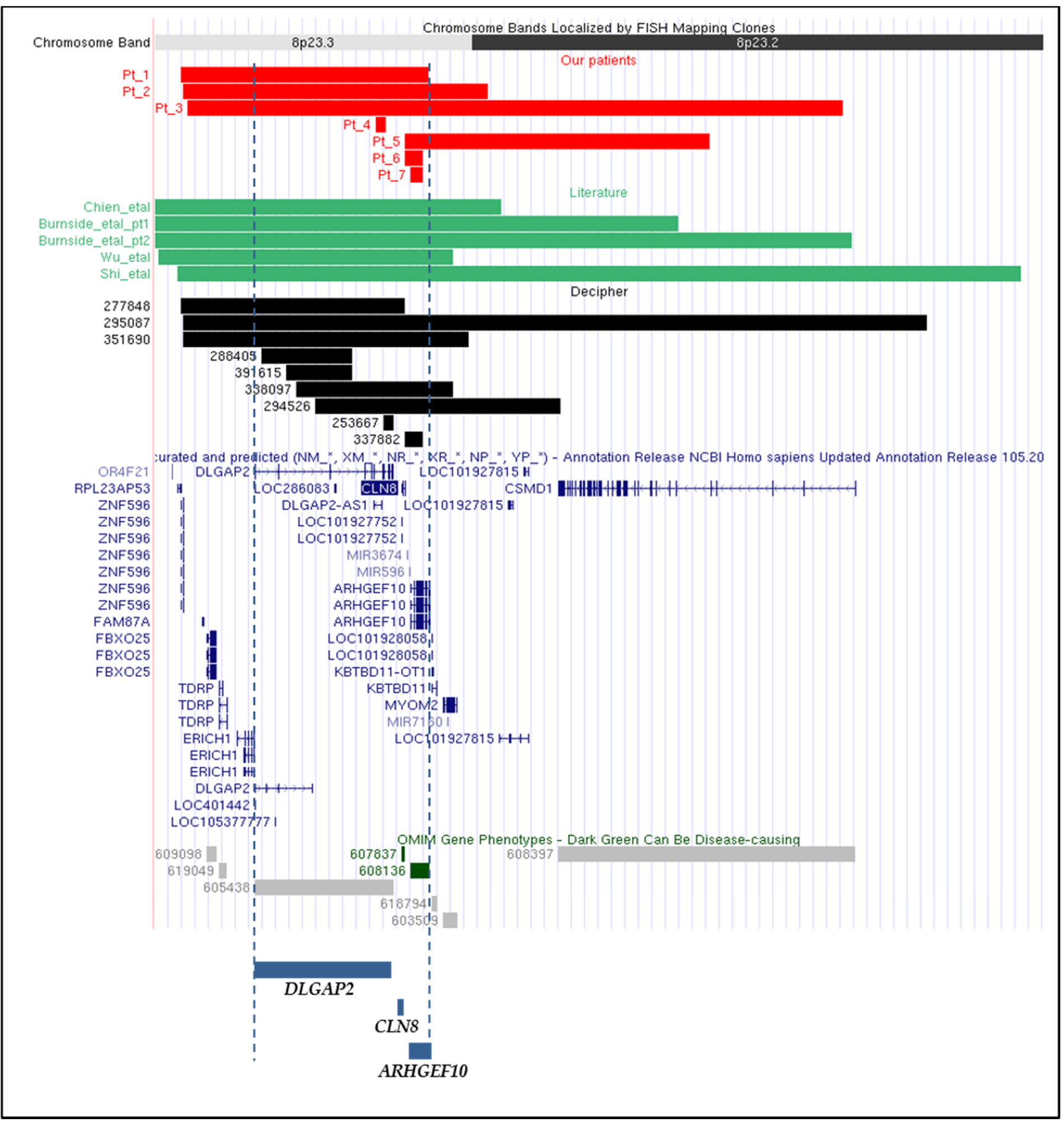

Figure 1. Physical map of the 8p23.2-pter region (nucleotides 1 to 6,000,000 GRCh37/hg19) adapted from the UCSC Genome Browser [20]: differently colored bars indicate the different genomic regions involved in the microdeletions of: our seven patients (RED bars), patients reported in the literature (GREEN bars), patients described in the DECIPHER database (BLACK bars). All curated and predicted NCBI RefSeq genes included in this region are annotated. Genes included in the candidate region are indicated below with BLUE bars. DARK GREEN bars point to OMIM-disease genes, whereas LIGHT GREY bars indicate genes not associated to any OMIM phenotype [17]. 
Table 1. Clinical and molecular genetics data of $8 p$ microdeleted patients described in the present work and in the literature.

\begin{tabular}{|c|c|c|c|c|c|c|c|c|c|c|c|c|c|}
\hline & & & & esent Work Patients & & & & & & Literature Patients & & & \\
\hline & Patient 1 & Patient 2 & Patient 3 & Patient 4 & Patient 5 & Patient 6 & Patient 7 & Shi et al., $2017[7]$ & $\begin{array}{l}\text { Burnside et al, } \\
\text { 2013 pt1 }[9]\end{array}$ & $\begin{array}{l}\text { Burnside et al., } 2013 \mathrm{pt} 2 \\
{[9]}\end{array}$ & $\begin{array}{l}\text { Chien et al., } 2010 \\
{[10]}\end{array}$ & Wu et al., 2010 & \multirow{7}{*}{$\begin{array}{l}\text { Total } \\
\text { Numbe } \\
\text { of } \\
\text { Patient }\end{array}$} \\
\hline Age at diagnosis & 13 & 4 & 16 & 2 & 13 & 38 & 12 & 5 & 2 & 4 & 12 & 1 & \\
\hline Sex & $\mathrm{M}$ & $\mathrm{M}$ & $\mathrm{M}$ & $\mathrm{M}$ & M & $\mathrm{M}$ & $\mathrm{F}$ & $\mathrm{M}$ & $\mathrm{F}$ & $\mathrm{M}$ & M & $\mathrm{F}$ & \\
\hline $\begin{array}{c}\text { Coordinates } \\
\text { (GRCh37/hy19) }\end{array}$ & $\begin{array}{l}\text { chr8: } 176475- \\
1892812\end{array}$ & $\begin{array}{l}\text { chr8:191530- } \\
\text { 2308985 }\end{array}$ & chr8:221611-4767606 & $\begin{array}{l}\text { chr8:1531691- } \\
1603483\end{array}$ & $\begin{array}{c}\text { chr8:17731454- } \\
3846288\end{array}$ & $\begin{array}{l}\text { chr8:1731454- } \\
1853939\end{array}$ & $\begin{array}{l}\text { chr8: 17744139- } \\
1857463\end{array}$ & chr8:158048-6004205 & chr8:1-3623904 & chr:1-14832134 & chr8:1-2400000 & $\begin{array}{l}\text { chr8:21000- } \\
2067000\end{array}$ & \\
\hline Size & $1.72 \mathrm{Mb}$ & $2.12 \mathrm{Mb}$ & $4.55 \mathrm{Mb}$ & $71.79 \mathrm{~kb}$ & $2.1 \mathrm{Mb}$ & $123 \mathrm{~kb}$ & $83.33 \mathrm{~kb}$ & $6.0 \mathrm{Mb}$ & $3.6 \mathrm{Mb}$ & $4.8 \mathrm{Mb}$ & $2.4 \mathrm{Mb}$ & $2.1 \mathrm{Mb}$ & \\
\hline Inheritance & & Maternal & de novo & de novo & $\begin{array}{c}\text { paternal } \\
\text { (father with } \\
\text { learning disability } \\
\text { and stuttering) }\end{array}$ & $\begin{array}{c}\text { inherited } \\
\text { (present in the } \\
\text { unaffected brother) }\end{array}$ & & de novo & de novo & de novo & & & \\
\hline $\begin{array}{c}\text { Coding gene(s) } \\
\text { content }\end{array}$ & $\begin{array}{c}\text { ORFAF21, } \\
\text { ZNF596,FBX'O25, } \\
\text { TDRP, } \\
\text { ERICH, } \\
\text { DLGAP2, } \\
\text { CLNS, } \\
\text { ARHGEF10 } \\
\text {. }\end{array}$ & 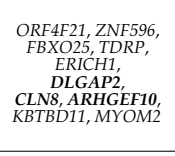 & 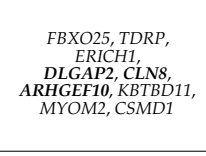 & DLGAP2 & $\begin{array}{c}\text { CLN8, ARGEFF10, } \\
\text { KBTBDI11 } \\
\text { YYM2, CSMD1 }\end{array}$ & CLN8, ARHGEF10 & ARHGEF10 & $\begin{array}{c}\text { ORF4F21, ZNF596, } \\
\text { FBXO25,TDRP, } \\
\text { ERICH1 } \\
\text { ELGAP2, CLN } 8, \\
\text { ARHGEF10, KBTBD11, } \\
\text { MYOM2, KSMDD1 }\end{array}$ & 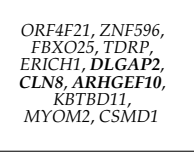 & 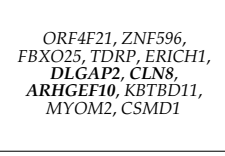 & 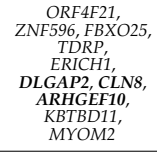 & 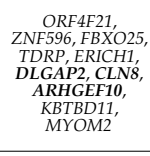 & \\
\hline ID & mild ID & & mild ID & & $\begin{array}{l}\text { mild } D D \text { at } 3 y \text {. } \\
\text { IQ }=91 \text { at } 13 \mathrm{y}\end{array}$ & & & + & & & + & + & $6 / 12$ \\
\hline DD & & + & - & - & + & + & + & + & + & + & + & + & $9 / 12$ \\
\hline $\begin{array}{l}\text { Language and } \\
\text { speech delay }\end{array}$ & + & & & & + & & + & + & + & - & + & & $6 / 12$ \\
\hline Motor impairment & $\begin{array}{c}\text { Motor instability, } \\
\text { dyspraxia }\end{array}$ & $\begin{array}{l}\text { Motor instability, } \\
\text { bal- } \\
\text { ancel coordination } \\
\text { problems, limb } \\
\text { hypotonia }\end{array}$ & & & - & $\begin{array}{l}\text { Fine and gross } \\
\text { coordination } \\
\text { problems }\end{array}$ & & $\begin{array}{c}\text { Balanced/coordination } \\
\text { problems }\end{array}$ & $\begin{array}{l}\text { Balanced/coordination } \\
\text { problems }\end{array}$ & & & & $5 / 12$ \\
\hline 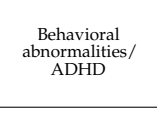 & & $\begin{array}{l}\text { Hyperkinetic } \\
\text { behavior, } \\
\text { irritability }\end{array}$ & & $\begin{array}{c}\text { Hyperkinetic } \\
\text { behavior, ADHD }\end{array}$ & $\begin{array}{c}\text { Hyperactivity, } \\
\text { aggressiveness, } \\
\text { impulsivenss, } \\
\text { stereouypes } \\
\text { behavior }\end{array}$ & & $\begin{array}{l}\text { Hyperkinetic } \\
\text { behavior, } \\
\text { hyperactity, } \\
\text { attention deficict, } \\
\text { aggressiveness }\end{array}$ & ADHD & - & - & ADHD & & $6 / 12$ \\
\hline Microcephaly & & & + & & & & - & + & $\begin{array}{l}\text { Microcephaly, } \\
\text { brachycephaly }\end{array}$ & + & - & + & $5 / 12$ \\
\hline $\begin{array}{c}\text { Fingers/ } \\
\text { toes anomalies }\end{array}$ & & & $\begin{array}{l}\text { Shortened } 4 \text { th toe of left } \\
\text { foot, bilateral broad 1st } \\
\text { toe, finger hyperlaxity }\end{array}$ & & $\begin{array}{c}\text { Bilateral } \\
\text { clinodactyly of the } \\
\text { 5th finger }\end{array}$ & & & & & Nail hypoplasia & & & $3 / 12$ \\
\hline Dysmophisms & (not specified) & - & $\begin{array}{l}\text { Bitemporal narrowing, } \\
\text { hypotelorism, } \\
\text { prograthism, premature } \\
\text { graying of hair }\end{array}$ & - & $\begin{array}{l}\text { Low-setears, } \\
\text { narrow palpebral } \\
\text { fissures, thin } \\
\text { vermillion of the } \\
\text { upper lip }\end{array}$ & - & & $\begin{array}{c}\text { low-set ears with } \\
\text { bilateral } \\
\text { prominence of the } \\
\text { antitragus, epicanthal } \\
\text { folds } \\
\text { and a long philtrum }\end{array}$ & $\begin{array}{c}\text { Mild maxillary, } \\
\text { flattening medial } \\
\text { epicanthal } \\
\text { folds with } \\
\text { upslanting } \\
\text { palpebral fissures, } \\
\text { preauricular pit } \\
\text { and bilateral } \\
\text { prominence of the } \\
\text { antititragus }\end{array}$ & 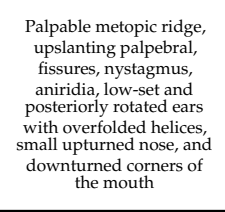 & - & $\begin{array}{l}\text { Hypertelorism, } \\
\text { long philtrum, } \\
\text { malformed ears }\end{array}$ & $7 / 12$ \\
\hline
\end{tabular}


Table 1. Cont.

\begin{tabular}{|c|c|c|c|c|c|c|c|c|c|}
\hline Epilepsy & & & & & & + & + & + & $3 / 12$ \\
\hline Other & $\begin{array}{c}\text { Myopia, } \\
\text { strabismus, } \\
\text { skeletal } \\
\text { anomalies }\end{array}$ & $\begin{array}{c}\text { Xerosis cutis, skin } \\
\text { anomalies, mild } \\
\text { hepatomegaly, } \\
\text { crebral } \\
\text { parenchymal } \\
\text { anomalies }\end{array}$ & $\begin{array}{l}\text { Short stature, eutrophic } \\
\text { skin, }\end{array}$ & $\begin{array}{l}\text { Hippocampal } \\
\text { anomalies heart } \\
\text { anomalies }\end{array}$ & $\begin{array}{l}\text { Perinatal distress, } \\
\text { jaundice, flat feet, } \\
\text { frequent } \\
\text { respiritory } \\
\text { infections }\end{array}$ & Scoliosis & $\begin{array}{l}\text { Emmetropia, } \\
\text { scoliosis, horshoe } \\
\text { kidney, } \\
\text { hypereosinophily, } \\
\text { teeth cavities, } \\
\text { hypotyroidism }\end{array}$ & Coartaction of the aorta & \\
\hline $\begin{array}{c}\text { Other CNVs } \\
\text { (GRCh37/ hg19)/ } \\
\text { additional genetic } \\
\text { data }\end{array}$ & & $\begin{array}{c}5 p 15.2 \\
\text { microdeletion } \\
\text { coordinates } \\
12200192-12849583 \\
\text { (maternal) }\end{array}$ & $\begin{array}{c}45, \mathrm{XY},-8[8] / \\
46, \mathrm{XY}, \mathrm{r}(8)(\mathrm{p} 23.2 \mathrm{q} 24.3)[42]\end{array}$ & & & $\begin{array}{l}\text { Absence of } \\
\text { mutations in } C L N 8 \\
\text { coding sequence } \\
\text { on the other allele }\end{array}$ & $\begin{array}{l}\text { 6q26 deletion } \\
\text { coordinates } \\
163274414- \\
163399757\end{array}$ & & \\
\hline
\end{tabular}

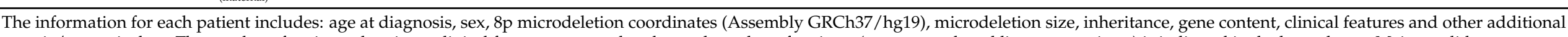

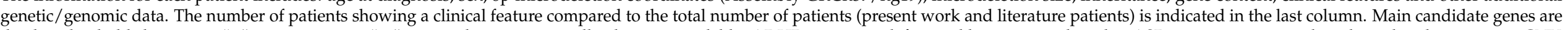

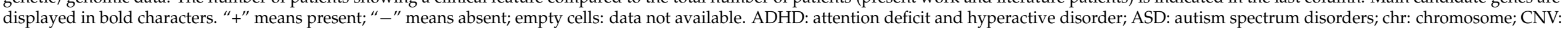
copy number variant; DD: developmental delay; ID: intellectual disability; IQ: intelligence quotient; y: years. 
Table 2 lists the genes comprised in the patients' microdeletions, their OMIM entry, when available, the encoded proteins and their assessed, putative or unknown main role, their association to disease, if applicable, and all inherent references. The last column of the table provides the pLI (probability of Loss of function Intolerance) score, a metric which ranges between 0 and 1 and measures the extent of tolerance of a given gene to heterozygous loss-of function variants [21,22], a parameter suitable to explore the role of genes contributing to the phenotype of microdeletion syndromes.

All genes map to 8p23.3, except the most centromeric CSMD1, which maps to 8p23.2. Noncoding genes localized at 8p23.2-pter are not included in the list because knowledge of their function is limited and most of them are not annotated in OMIM.

Out of the 11 protein coding genes encompassing the deletion intervals of our patients, DLGAP2 and ARHGEF10 appear to be, according to their expression profile and the assessed role in neural morphogenesis, differentiation and function [13-16], bona fide candidates for neurodevelopmental disorders. Interestingly, DLGAP2, a "synaptic" gene associated with autism [13], is the only gene lost in Patient 4, who carries the smallest microdeletion $(71.79 \mathrm{~kb})$ and presents behavioral issues (Table 1); ARHGEF10 is the only gene lost in the second smallest microdeletion $(83.33 \mathrm{~kb})$, found in Patient 7, who also displays a hyperkinetic behavior (Table 1). ARHGEF10, together with CLN8, also falls within the $123 \mathrm{~kb}$ deletion of patient 6 who has motor coordination problems and epilepsy (Table 1). Both DLGAP2 and ARHGEF10 also map within the deletion intervals of the remaining four patients. The CLN8 gene is involved in lipid synthesis, transport, or sensing [23]. The FBXO25 and KBTBD11 genes have cell cycle regulation and metabolic functions [24,25], while TDRP is involved in spermatogenesis [26] and MYOM2 encodes a strictly muscularrelated protein [27]. Even more limited is the knowledge on the remaining OR4F21, ZNF596, ERICH1 and CSMD1 microdeletion genes.

RNA-seq data from the GTEx Portal show a high level of expression in the whole brain for DLGAP2, KBTBD11 and CSMD1, and in some nervous system tissues for ZNF596 (cerebellum) and CLN8 (spinal cord) [28].

Comparison of the microdeletions of our seven patients with those of the five patients reported in the literature highlighted a similar extent and an identical gene content between the microdeletion of our Patient 2 and the literature smallest microdeletion which allowed to identify the CR $[7,11]$. It also allowed to point out the presence in Patient 5 of another microdeletion, similar in length, but staggered. In addition, while the largest microdeletion in our series (Patient 3) stands between those reported in Patients 1 and 2 by Burnside [9], the increasingly smaller deletion intervals of $1.72 \mathrm{Mb}, 123 \mathrm{~kb}, 83.33 \mathrm{~kb}$ and $71.79 \mathrm{~kb}$ in our Patients 1, 6, 7 and 4, respectively, provided the tool to address a genotype-phenotype analysis by cross evaluating the clinical signs displayed by our patients and the reported microdeleted patients. As detailed in Table 1, growth delay combined to mild cognitive impairment and/or ASD manifestations and a few dysmorphic signs, particularly microcephaly, emerged as core features of both the seven newly characterized patients and the five previously reported ones. However not all the listed signs were present across patients and their combination was variable, apparently not dependent on the deletion size (Table 1). In order to better define the variable clinical expressivity of 8p23.2-pter microdeletion, 9 additional individuals from the DECIPHER database [29] were included in the genomic and clinical comparison, summing up to a total of 21 individuals (Table 3). DECIPHER patients 396027, 396034, 396025, 396345 and 396353, referred to the same laboratory and carrying 8p23.3 microdeletions with the same extension and identical end points, were excluded from our analysis as we could not discriminate between their possible familial relationship and a longitudinal study of the same individual at different ages. DECIPHER patient 394930 has been excluded because he carries the same 8p23.3 microdeletion and a large pathogenic rearrangement involving chromosome 12. 
Table 2. Coding genes included in 8p23.2-pter region.

\begin{tabular}{|c|c|c|c|c|c|}
\hline $\begin{array}{c}\text { Human Gene } \\
\text { Symbol/OMIM Entry }\end{array}$ & Gene Full Name & $\begin{array}{l}\text { Main Biological } \\
\text { Activity }\end{array}$ & Reference & OMIM Disease Association & pLI Score \\
\hline OR4F21 & $\begin{array}{l}\text { Olfactory receptor family } 4 \text { subfamily F } \\
\text { member } 21\end{array}$ & Olfactory receptor & np & $\mathrm{np}$ & $\mathrm{np}$ \\
\hline ZNF596 & Zinc finger protein 596 & Transcriptional regulation & $\mathrm{np}$ & np & 0 \\
\hline $\begin{array}{l}\text { FBXO25 } \\
/^{*} 609098\end{array}$ & F-box protein 25 & $\begin{array}{l}\text { Substrate-recognition component of the SCF } \\
\text { (SKP1-CUL1-F- box protein)-type E3 } \\
\text { ubiquitin ligase complex. }\end{array}$ & [24] & $\mathrm{np}$ & 0 \\
\hline ERICH1 & Glutamate-rich 1 & Unknown & $\mathrm{np}$ & $\mathrm{np}$ & 0 \\
\hline $\begin{array}{l}D L G A P 2 \\
/ * 605438\end{array}$ & $\begin{array}{c}\text { Discs, large (Drosophila) homolog-associated } \\
\text { protein } 2\end{array}$ & $\begin{array}{l}\text { Role in the molecular organization of } \\
\text { synapses and neuronal cell signaling. } \\
\text { Adapter protein linking ion channel to the } \\
\text { sub-synaptic cytoskeleton }\end{array}$ & [16] & $\mathrm{np}$ & 1 \\
\hline $\begin{array}{l}\text { CLN8 } \\
\mu^{*} 607837\end{array}$ & $\begin{array}{l}\text { Ceroid-lipofuscinosis, neuronal } 8 \text { (epilepsy, } \\
\text { progressive with mental retardation) }\end{array}$ & Lipid synthesis, transport, or sensing & [23] & $\begin{array}{l}\text { Ceroid lipofuscinosis 8, AR (\# 600143) } \\
\text { Ceroid lipofuscinosis, neuronal, 8, } \\
\text { Northern epilepsy variant, AR (\# 610003) }\end{array}$ & 0 \\
\hline $\begin{array}{c}\text { ARHGEF10 } \\
/ * 608136\end{array}$ & $\begin{array}{l}\text { Rho guanine nucleotide exchange factor (GEF) } \\
\qquad 10\end{array}$ & $\begin{array}{l}\text { Membrane trafficking and neural } \\
\text { morphogenesis }\end{array}$ & {$[14,15]$} & $\begin{array}{l}\text { ?Slowed nerve conduction velocity, AD } \\
\text { (\# 608236) }\end{array}$ & 0 \\
\hline $\begin{array}{c}\text { KBTBD11 } \\
{ }^{*} 618794\end{array}$ & $\begin{array}{l}\text { Kelch repeat and BTB (POZ) domain } \\
\text { containing } 11\end{array}$ & $\begin{array}{l}\text { Protein degradation, thereby affecting } \\
\text { differentiation, homeostasis, metabolism, } \\
\text { cell signaling, and oxidative stress response }\end{array}$ & [25] & $\mathrm{np}$ & 0.06 \\
\hline $\begin{array}{l}\text { MYOM2 } \\
/ * 603509\end{array}$ & Myomesin 2 & $\begin{array}{l}\text { Major component of the vertebrate } \\
\text { myofibrillar M band }\end{array}$ & [27] & $\mathrm{np}$ & 0 \\
\hline $\begin{array}{l}\text { CSMD1 } \\
/ * 608397\end{array}$ & CUB and Sushi multiple domains 1 & Role in central nervous system development & [12] & $\mathrm{np}$ & 1 \\
\hline
\end{tabular}

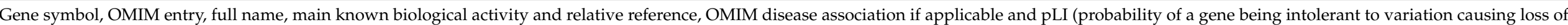
gene function) score from GnomAD are reported. "np" stands for: not present $[17,21]$. 
Table 3. Clinical and molecular genetics data of $8 \mathrm{p}$ microdeleted patients described in the DECIPHER database [29].

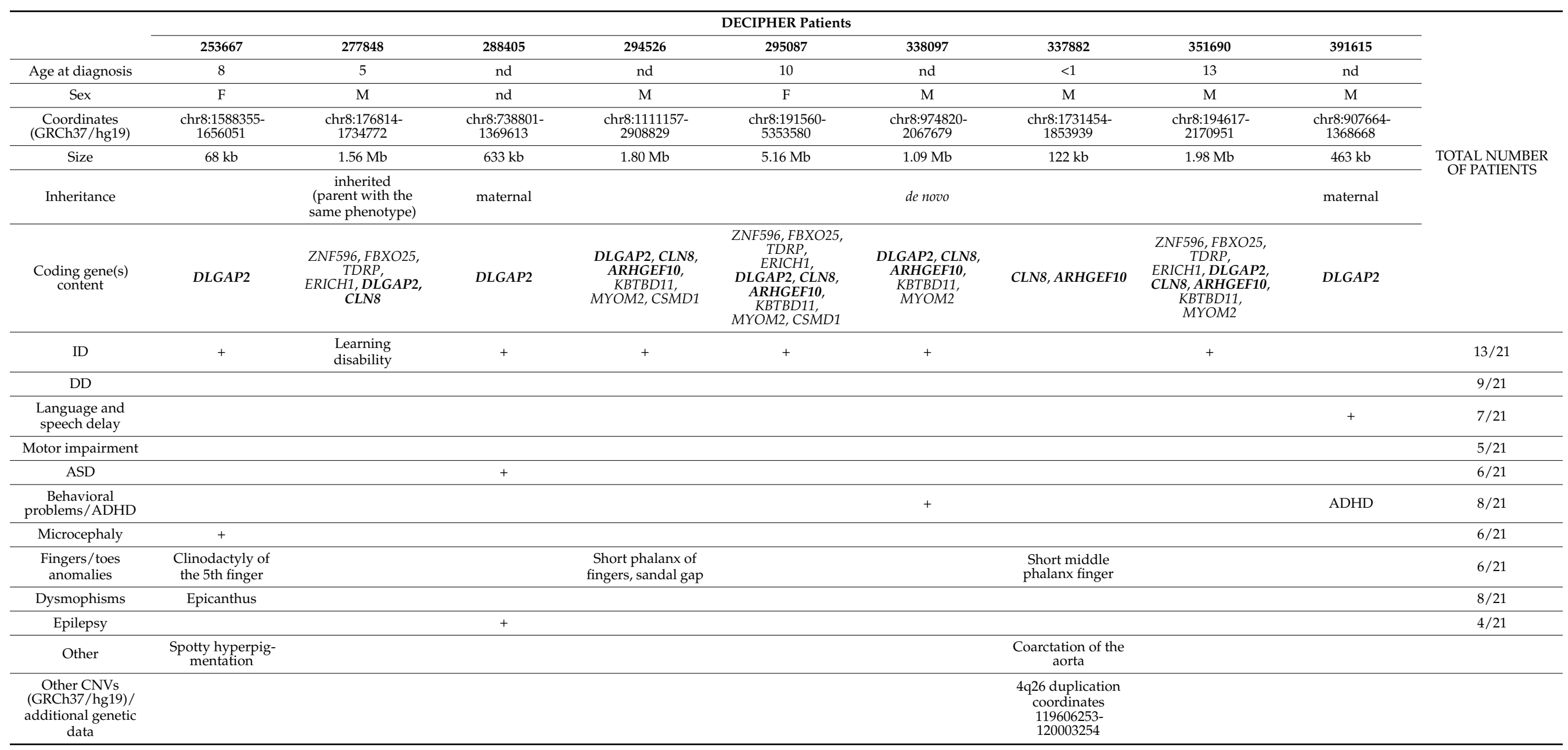

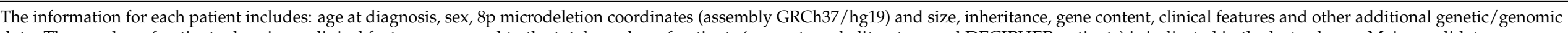

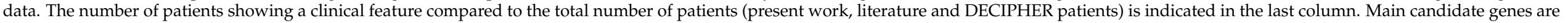

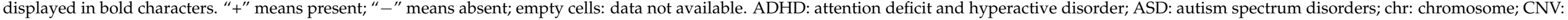
copy number variant; DD: developmental delay; ID: intellectual disability. 
Evaluation of the expanded cohort of 21 8p23.2-pter microdeleted patients confirmed that the main phenotype is variably compounded by ID (13/21), DD (9/27), including language and/or speech delay $(7 / 21)$ and motor impairment $(5 / 21)$, behavioral anomalies/ADHD (8/21), ASD (6/21), dysmorphisms (8/21), microcephaly (6/21), fingers/toes anomalies $(6 / 21)$, and epilepsy $(4 / 21)$ (Table 3$)$.

\section{Discussion}

We overviewed seven new patients carrying microdeletions sized from $71.79 \mathrm{~kb}$ to $4.55 \mathrm{Mb}$ encompassing the 8p23.2-pter region. All microdeletions partially overlap with the CR including the FBXO25, DLGAP2, CLN8, ARHGEF10 and MYOM2 genes, that have been previously pointed out by Wu et al. and Shi et al. [7,11]. Loss of these genes may be of pathogenic relevance as 8p23.2-pter CNVs are rarely reported in the healthy population according to the DGV database [8]. Patient 3 should be considered more prudently compared to other patients since conventional cytogenetic analysis revealed a low-level mosaicism for chromosome 8 monosomy, non excludable by array-CGH analysis, making difficult to assess its contribution to the clinical phenotype.

Our patients have been referred for variable clinical features consistent with those described in 5 previously reported microdeleted patients (Table 1) and in 9 patients recorded in the DECIPHER Database, summing up to a total of 21 individuals (Table 3). The small number of the evaluated patients so far and the lack of records for specific signs in a few cases does not allow to calculate an accurate frequency for each considered feature. In addition, since age at diagnosis spans between $<1$ to 38 years, incompletely evaluated late onset features in some patients must be also taken into account as contributors to the phenotypic variability. However, considering the entire composite cohort, ID and DD, including speech and/or motor delay, are present in the majority of individuals. Other common features in decreasing trend are behavioral anomalies/ADHD, ASD, dysmorphisms and microcephaly. We also observed fingers/toes anomalies in few individuals, whereas epilepsy/seizure was reported only occasionally.

Overall, microdeletions arose de novo in 5 patients and were inherited in 6 out of the 21 patients herein surveyed. The familial cases, including one paternal transmission (our Patient 5), three maternal transmissions (our Patient 2, and DECIPHER patients 288405 and 391615) and two unknown transmissions (brother of Patient 6 and DECIPHER patient 277848) attest the relatively mild overall phenotype of even large microdeletion carriers and their spared reproductive fitness. This observation values the provision of genetic counseling and the careful collection of familial history also in those that are apparently sporadic cases. Recognition of the unaffected brother of Patient 6 and the apparently asymptomatic mother of Patient 2 highlights a possible defect of penetrance which may lead to underestimate 8p23.2-pter microdeletion carriers. However, inaccurate clinical evaluation of these asymptomatic carriers cannot be excluded since some patients are characterized by very mild clinical features. Additional cases are required to strengthen the incomplete penetrance of 8p23.2-pter microdeletions.

Although sharing deleted genes, the 21 different microdeletions analyzed do not appear to share common breakpoints, a finding which may account for non recurrent microdeletions at the population level $[30,31]$. The different rearrangement sizes, genomic extents, and breakpoint positions suggest non-homologous end joining (NHEJ) and replication mechanisms as the main causative drivers of the described microdeletions [32]. The analysis of the deletion intervals does not highlight a single overlapping region. However, the smallest microdeletions identified in Patients 4, 6 and 7, as well as in DECIPHER patients 253667, 288405, 337882 and 391615, point out two CRs, one including DLGAP2 and the other ARHGEF10 (Figure 1, Tables 1 and 3).

ARHGEF10 (Rho guanine nucleotide exchange factor 10) encodes a guanine-nucleotide exchange factor (GEF) for the Rho family of GTPase proteins (RhoGEFs) [33]. The function of ARHGEF10 has not been completely elucidated, but recent evidence suggests it could be specifically linked to the membrane trafficking pathway $[14,15,34]$. A neuronal role 
for ARHGEF10 has emerged with the identification of a familial Thr332Ile heterozygous mutation, which causes constitutive activation of GEF, and which is associated to autosomal dominant non-progressive slow nerve conduction velocities and thin peripheral nerve myelinization without clinical phenotype (OMIM \#608236) (Table 2) [34,35]. ARHGEF10 variants have been also associated to schizophrenia and to Charcot-Marie Tooth disease type 1A (CMT1A) [36-39]. In accordance with this presumptive role, DECIPHER patient 368323, carrying an SNV (single nucleotide variant) of uncertain clinical significance in ARHGEF10, mainly showed global developmental delay, postnatal microcephaly, encephalopathy and seizure, that are typical features of 8p23.2-pter patients (Tables 1 and 3). In addition, ARHGEF10 is included among autism genes with a suggestive evidence score in the SFARI database (score 3) [40].

DLGAP2 (discs, large Drosophila homolog-associated protein 2) belongs to the DLGAP family of scaffolding proteins acting in the post-synaptic density (PSD), a highly specialized matrix involved in transmission of neuronal signals across the synaptic junction $[16,41]$. Several studies pointed out an association between DLGAP2 and ASD, obsessive-compulsive disorder (OCD) and schizophrenia [10,11,13,42-44]. In particular, two duplications of $D L G A P 2$ have been recently reported in an ASD cohort [45]. Accordingly, DLGAP2 is also present in the SFARI Gene database with a suggestive evidence score of 3 [40]. Most importantly, and conversely to ARHGEF10, DLGAP2 is a brain-specific expressed and dosage-sensitive gene with a pLI score of 1 (Table 2) [21], indicating it may contribute to the clinical phenotype of 8p23.2-pter microdeleted patients.

In 2017 Shi et al. proposed DLGAP2 as candidate gene for microcephaly [7], given that polymorphisms in DLGAP2 have been associated to orbital frontal cortex (OFC) white matter volume alterations in OCD patients [46]. Moreover, DLGAP2 interacts with NRXN1, a pre-synaptic cell-adhesion molecule (Figure 2A) and CASK, another scaffolding protein (Figure 2C) and mutations in both NRXN1 and CASK are associated to neurodevelopmental and neurocognitive disabilities and microcephaly [47-49]. Disruption of the CASKNeurexin interaction was recently proposed to be strictly linked to microcephaly onset in CASK-mutated patients [50]. Weakening of the DLGAP2-NRXN1 interaction upon DLGAP2 haploinsufficiency and interfering with the NRXN1-CASK interaction might concur to microcephaly onset also in 8p23.2-pter patients. In our cohort, the presence of microcephaly only in Patient 3, which carries a $4.55 \mathrm{Mb}$ microdeletion encompassing 9 genes and a mosaic karyotype with a chromosome 8 monosomy cell line, does not allow to confirm DLGAP2 as the main candidate gene for microcephaly. In addition, microdeleted patients in the literature displaying microcephaly were shown to carry large deletions, leaving open the implication of other 8p23.2-pter genes. In particular, ARHGEF10 is involved in neuronal morphogenesis and DECIPHER Patient 368323, which carries an ARHGEF10 SNV, presents microcephaly; CSMD1 and KBTBD11 are brain-specific expressed genes, and CSMD1 is also dosage-sensitive. The strict connection between brain genes and microcephaly is well-documented in the literature [51-53].

Both DLGAP2 and ARHGEF10 could be potential candidates for behavioral disorders,

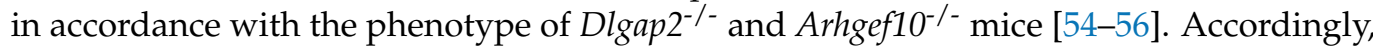
our Patients 2, 4, 5 and 7, which carry 8p23.2-pter microdeletions involving DLGAP2 and/or ARHGEF10, are characterized by hyperactivity/hyperkinetic behavior and/or aggressiveness (Table 1).

Based on its dosage-sensitivity, the brain-specific expression and the de novo origin of Patient's 4 microdeletion, DLGAP2 seems to be a stronger candidate than ARHGEF10 for both the neurodevelopmental and behavioral phenotypes. The causative role of ARHGEF10 appears weaker since none of the microdeletions involving ARHGEF10 without DLGAP2 (Patients 5, 6 and 7), were demonstrated to be de novo. Moreover, the asymptomatic brother of Patient 6 may be interpreted as a sign of reduced penetrance, as above mentioned, but could also be evidence against causality. 


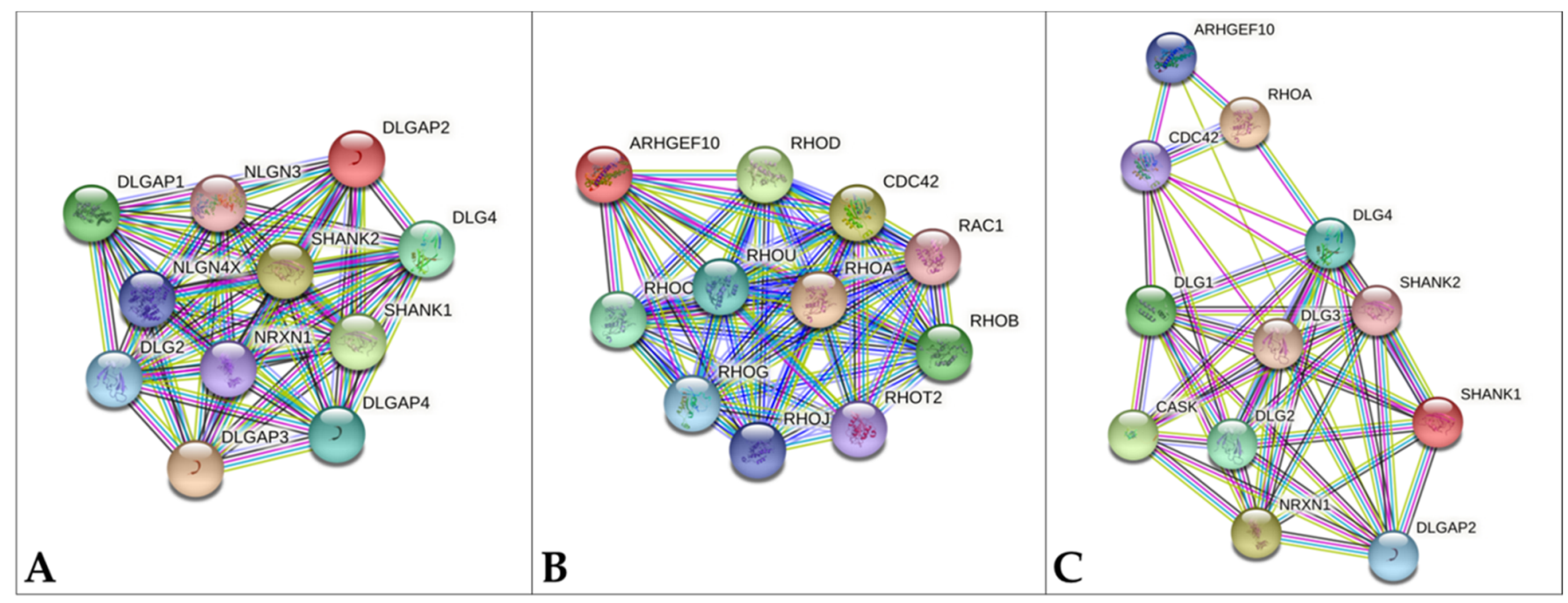

Figure 2. Protein-protein interaction in STRING database [57]. (A) DLGAP2 network, (B) ARHGEF10 network (C) ARHGEF10 and DLGAP2 common network. The top ten interactors for each gene are shown. Colored lines indicate different kinds of interactions. Blue: known interaction from curated databases; violet: known interaction experimentally determined; green: predicted interaction for gene neighborhood; red: predicted interaction for gene fusion; dark blue: predicted interaction for gene co-occurrence; yellow: interaction based on text mining; black: interaction based on gene-expression; light blue: interaction based on protein homology.

Therefore, for these latter patients, pathogenic mechanisms other than ARHGEF10 loss, are possible. In particular, the microdeletion could impact the expression of genes flanking the deleted region, such as the nearby DLGAP2, through a position effect mechanism or by disruption of the topological associated domains (TADs) architecture. Indeed, in the 8p23.2-pter region two adjacent TADs are present with a boundary localized between MYOM2 and CSMD1 (Figure 3). For example, the microdeletion of Patient 5, which involves the boundary but not DLGAP2, could cause neurodevelopmental and behavioral consequences due to DLGAP2 deregulation. Assessment of DLGAP2 expression levels in patients which deletion breakpoints map to the boundary of the two main 8p23.2-pter architectural domains might furnish preliminary insights.

Despite all the above-mentioned considerations, ARHGEF10 deserves to be evaluated in further microdeleted patients because of its documented role in neuronal morphogenesis and its joined action with DLGAP2 on post-synaptic scaffolding proteins. The family of post-synaptic scaffolding proteins includes members of the SHANK, DLG and DLGAP subfamilies, which interact in post-synapses [16]. As shown in Figure 2A, DLGAP2 interacts with SHANK1-2, DLG2-4 and DLGAP1-2-3. Disruption of the network of scaffolding proteins alters the homeostasis of the PSD, contributing to various neuropsychiatric conditions, such as autism spectrum disorders, intellectual disability, behavioral problems, schizophrenia, and bipolar disorders [16,58-62].

At the same time, ARHGEF10 defects, which cause alterations in Rho GTPases function, could have an indirect effect on the activity of scaffolding proteins (Figure 2C). The STRING database shows the interaction between ARHGEF10 and small GTPases, such as RhoA and CDC42 (Figure 2B), which play an important role in regulating the shape of most neuron cell types and interact with scaffolding proteins, such as SHANK [63,64]. A role for GTPases in neurodevelopmental disorders, especially autism $[59,62]$ is attested by the association of RhoA and CDC42 genes to ASD [65-67].

Based on the clinical phenotype and on the CR $[7,11]$, we pointed out for the first time, motor impairment as another clinical feature associated with 8p23.2-pter microdeletions and linked it to CLN8 and ARHGEF10, the only genes included in the $123 \mathrm{~kb}$ deletion of our Patient 6, which showed fine and gross coordination problems. The CLN8 (Ceroidlipofuscinosis neuronal 8) gene belongs to the TLC (TRAM, Lag1, and CLN8 homology 
domains) superfamily and has a role in the biosynthesis and metabolism of lipids and in the protection of proteins from proteolysis [23]. Homozygous genetic alterations of CLN8 are associated with neuronal ceroid lipofuscinosis (NCL) (OMIM \#600143), a genetically heterogeneous group of neurodegenerative disorders mainly characterized by seizures and progressive neurological deterioration, which result in dementia, ataxia, visual failure, and various forms of abnormal movement. Despite the fact that a mutation of CLN8 in the non deleted allele of Patient 6 has been ruled out and that, to date, a clinical phenotype has never been reported for CLN8 heterozygous deletion/mutation, a higher risk for motor impairment should be assessed in future CLN8 heterozygous deleted patients.

Since also CLN8, which maps between DLGAP2 and ARHEGF10, seems to be potentially clinically relevant, the two CRs could be merged into a single candidate region, including DLGAP2, CLN8 and ARHGEF10, that could be a valuable landmark for future investigations of additional 8p23.2-pter microdeleted patients. This region is more restricted compared to the previously proposed CR $[7,11]$.

As regards the pronounced clinical variability observed in 8p23.3-pter patients it may result from their genetic heterogeneity, linked to microdeletions size and gene content. Beyond those involved in the actually restricted candidate region, other genes less frequently included in 8p23.2-pter microdeletions may cooperate to the clinical spectrum. Examples are CSMD1 in 8p23.2, a dosage-sensitive gene associated to ASD, schizophrenia and epilepsy [68-70] and FBXO25, recently associated to neuropsychiatric disorders [71]. Both genes are not included in most of the microdeletions reported to date, but they might act as phenotypic modifiers in patients with microdeletions spanning until the 8p23.2 or 8 p23.3 regions, respectively. Although we focused our attention on coding genes, the 8p23.2-pter region includes several noncoding genes for different types of regulatory RNAs, whose microdeletion could also have an effect on the clinical phenotype. The contribution to the clinical phenotype of 8p23.3-pter patients of several other coding or noncoding genes, remains to be identified. Dysmorphisms for example were reported only in patients carrying larger microdeletions, not involving only DLGAP2 and/or ARHGEF10, and this coincidence needs to be confirmed.

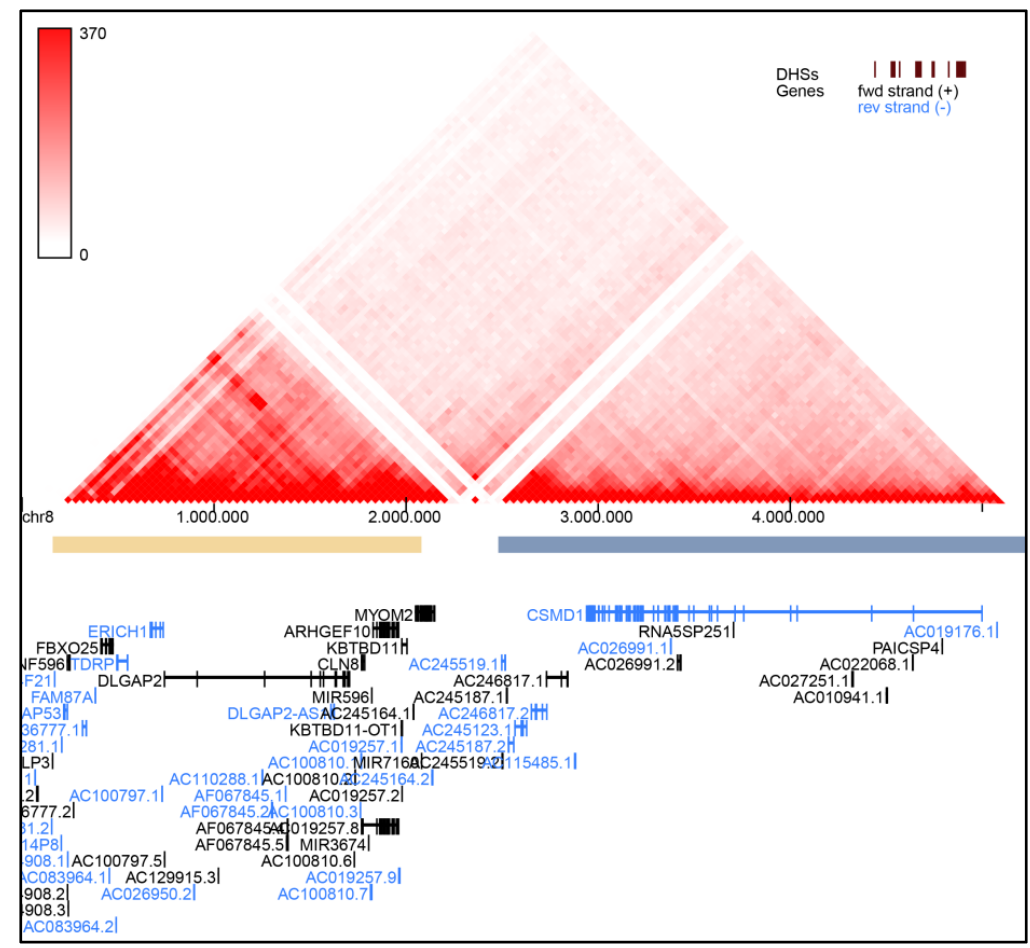

Figure 3. Topological associated domains (TADs) in 8p23.2-pter region based on Hi-C data performed by YUE Lab website [72]. 
In addition, several genomic and epigenetic mechanisms may contribute to the phenotypic variability of 8 p23.2-pter patients.

First, the genetic make up may influence the severity of the phenotype. The presence of other CNVs or mutations in the genome could have an additive effect on the clinical phenotype, as exemplified by Patients 2 and 7 additional CNVs, namely 5p15.2 microdeletion and $6 \mathrm{q} 26$ microduplication. Although these $\mathrm{CNVs}$ could be classified as likely benign according to international criteria, there could be a pathogenic effect in an 8p23.2-pter deleted background.

Second, epigenetic mechanisms may also play a role. In particular, DLGAP2 is predicted to be a maternally imprinted gene [73]. Although it seems to be expressed from both alleles in whole brain, the effect of its deletion on the severity of the clinical phenotype could be dependent on its parental origin. In patients carrying the microdeletion on the paternal allele, the effect of DLGAP2 loss could be worst. In favor of this hypothesis, the DLGAP2 microdeletions identified in the OCD and the ASD cohorts are both paternally inherited [42,45]. In order to support this hypothesis, the parental origin of the deleted allele should be checked, even in patients with a de novo origin of the microdeletion.

\section{Conclusions}

In conclusion, this study expands the limited number of described patients carrying microdeletions involving the 8 p23.2-pter region. Comparison of the 7 novel patients with the 5 previously reported and the additional 9 recorded in DECIPHER confirms the association to a variable clinical phenotype, mainly characterized by ID/DD, including language and/or speech delay and motor impairment, behavioral anomalies/ADHD, ASD, dysmorphisms and microcephaly. The analysis of small microdeletions allowed us to dissect the previously proposed $C R$, delineating a new candidate region including three 8p23.3 genes: DLGAP2, CLN8 and ARHGEF10. Out of these three genes, DLGAP2 is the more robust candidate due to its pLI score and its brain-specific expression, which account for the neurodevelopmental-specific effect of its loss. Investigation of novel patients will permit to validate the pathogenic role of DLGAP2, define how the two contiguous genes CLN8 and ARHGEF10 might contribute to the clinical phenotype and determine the role of other 8p23.2-pter genes.

Author Contributions: Conceptualization, I.C. and M.P.R.; funding acquisition, L.L. and M.P.R.; Investigation, I.C.; project administration, M.P.R.; resources, I.C., M.G., A.P.C., S.B., C.B., M.P.C., R.C., F.E., F.F., O.G., E.G., M.M., A.P., C.R., M.S. and M.P.R.; visualization, I.C.; writing—original draft, I.C.; writing - review and editing, L.L. and M.P.R. All authors have read and agreed to the published version of the manuscript.

Funding: This work was partially supported by the Italian Ministry of Health funding to Istituto Auxologico Italiano (RC 08C922 2019). The Biobank of the Laboratory of Human Genetics-IRCCS G. Gaslini, member of the "Network Telethon of Genetic Biobanks" (project no. GTB18001) funded by Telethon Italy, and of the EuroBioBank network, provided us with specimens of the lymphoblastoid cell line from Patient 3.

Institutional Review Board Statement: The study was conducted according to the guidelines of the Declaration of Helsinki, and approved by the Institutional Review Board of Istituto Auxologico Italiano (protocol code 08C922 approved on 16 April 2019).

Informed Consent Statement: Informed consent was obtained by the Clinical Geneticists from parents/tutors of the patients, from the healthy carrier or from the adult patients themselves.

Data Availability Statement: Not applicable.

Acknowledgments: We would like to thank the patients and their families. We would also like to thank Francesca Romana Grati and Daniela Giardino, respectively actual and former coordinators of the Cytogenetics/Cytogenomics working group of the Italian Society of Human Genetics (SIGU), for support to our study and Nicola Manfrini for language editing of the manuscript.

Conflicts of Interest: The authors declare no conflict of interest. 


\section{References}

1. Lo Bianco, M.; Vecchio, D.; Timpanaro, T.A.; Arena, A.; Macchiaiolo, M.; Bartuli, A.; Sciuto, L.; Presti, S.; Sciuto, S.; Sapuppo, A.; et al. Deciphering the Invdupdel(8p) Genotype-Phenotype Correlation: Our Opinion. Brain Sci. 2020, 10, 451. [CrossRef] [PubMed]

2. Hollox, E.J.; Barber, J.C.; Brookes, A.J.; Armour, J.A. Defensins and the dynamic genome: What we can learn from structural variation at human chromosome band 8p23.1. Genome Res. 2008, 18, 1686-1697. [CrossRef] [PubMed]

3. Rowe, L.R.; Lee, J.Y.; Rector, L.; Kaminsky, E.B.; Brothman, A.R.; Martin, C.L.; South, S.T. U-type exchange is the most frequent mechanism for inverted duplication with terminal deletion rearrangements. J. Med. Genet. 2009, 46, 694-702. [CrossRef] [PubMed]

4. Yu, S.; Fiedler, S.; Stegner, A.; Graf, W.D. Genomic profile of copy number variants on the short arm of human chromosome 8. Eur. J. Hum. Genet. 2010, 18, 1114-1120. [CrossRef]

5. Ballarati, L.; Cereda, A.; Caselli, R.; Selicorni, A.; Recalcati, M.P.; Maitz, S.; Finelli, P.; Larizza, L.; Giardino, D. Genotype-phenotype correlations in a new case of 8p23.1 deletion and review of the literature. Eur. J. Med. Genet. 2011, 54, 55-59. [CrossRef] [PubMed]

6. Kato, T.; Inagaki, H.; Miyai, S.; Suzuki, F.; Naru, Y.; Shinkai, Y.; Kato, A.; Kanyama, K.; Mizuno, S.; Muramatsu, Y.; et al. The involvement of U-type dicentric chromosomes in the formation of terminal deletions with or without adjacent inverted duplications. Hum. Genet. 2020, 139, 1417-1427. [CrossRef]

7. Shi, S.; Lin, S.; Chen, B.; Zhou, Y. Isolated chromosome 8p23.2pter deletion: Novel evidence for developmental delay, intellectual disability, microcephaly and neurobehavioral disorders. Mol. Med. Rep. 2017, 16, 6837-6845. [CrossRef]

8. DGV. Database of Genomic Variants. Available online: http://dgv.tcag.ca/dgv/app/home (accessed on 6 February 2021).

9. Burnside, R.D.; Pappas, J.G.; Sacharow, S.; Applegate, C.; Hamosh, A.; Gadi, I.K.; Jaswaney, V.; Keitges, E.; Phillips, K.K.; Potluri, V.R.; et al. Three cases of isolated terminal deletion of chromosome $8 \mathrm{p}$ without heart defects presenting with a mild phenotype. Am. J. Med. Genet. Part A 2013, 161, 822-828. [CrossRef]

10. Chien, W.H.; Gau, S.S.; Wu, Y.Y.; Huang, Y.S.; Fang, J.S.; Chen, Y.J.; Soong, W.T.; Chiu, Y.N.; Chen, C.H. Identification and molecular characterization of two novel chromosomal deletions associated with autism. Clin. Genet. 2010, 78, 449-456. [CrossRef]

11. Wu, Y.; Ji, T.; Wang, J.; Xiao, J.; Wang, H.; Li, J.; Gao, Z.; Yang, Y.; Cai, B.; Wang, L.; et al. Submicroscopic subtelomeric aberrations in Chinese patients with unexplained developmental delay/mental retardation. BMC Med. Genet. 2010, 11, 72. [CrossRef]

12. Kraus, D.M.; Elliott, G.S.; Chute, H.; Horan, T.; Pfenninger, K.H.; Sanford, S.D.; Foster, S.; Scully, S.; Welcher, A.A.; Holers, V.M. CSMD1 is a novel multiple domain complement-regulatory protein highly expressed in the central nervous system and epithelial tissues. J. Immunol. 2006, 176, 4419-4430. [CrossRef] [PubMed]

13. Pinto, D.; Pagnamenta, A.T.; Klei, L.; Anney, R.; Merico, D.; Regan, R.; Conroy, J.; Magalhaes, T.R.; Correia, C.; Abrahams, B.S.; et al. Functional impact of global rare copy number variation in autism spectrum disorders. Nature 2010, 466, 368-372. [CrossRef] [PubMed]

14. Shibata, S.; Kawanai, T.; Hara, T.; Yamamoto, A.; Chaya, T.; Tokuhara, Y.; Tsuji, C.; Sakai, M.; Tachibana, T.; Inagaki, S. ARHGEF10 directs the localization of Rab8 to Rab6-positive executive vesicles. J. Cell Sci. 2016, 129, 3620-3634. [CrossRef]

15. Shibata, S.; Teshima, Y.; Niimi, K.; Inagaki, S. Involvement of ARHGEF10, GEF for RhoA, in Rab6/Rab8-mediating membrane traffic. Small Gtpases 2019, 10, 169-177. [CrossRef]

16. Rasmussen, A.H.; Rasmussen, H.B.; Silahtaroglu, A. The DLGAP family: Neuronal expression, function and role in brain disorders. Mol. Brain 2017, 10, 43. [CrossRef] [PubMed]

17. OMIM. Online Mendelian Inheritance in Man. Available online: https:/ / www.omim.org/ (accessed on 6 February 2021).

18. Lichter, P.; Cremer, T.; Borden, J.; Manuelidis, L.; Ward, D.C. Delineation of individual human chromosomes in metaphase and interphase cells by in situ suppression hybridization using recombinant DNA libraries. Hum. Genet. 1988, 80, 224-234. [CrossRef] [PubMed]

19. Catusi, I.; Recalcati, M.P.; Bestetti, I.; Garzo, M.; Valtorta, C.; Alfonsi, M.; Alghisi, A.; Cappellani, S.; Casalone, R.; Caselli, R.; et al. Testing single/combined clinical categories on 5110 Italian patients with developmental phenotypes to improve array-based detection rate. Mol. Genet. Genom. Med. 2020, 8, e1056. [CrossRef]

20. UCSC Genome Browser. Available online: https://genome.ucsc.edu/ (accessed on 6 February 2021).

21. GnomAD. Genome Aggregation Database. Available online: https://gnomad.broadinstitute.org/ (accessed on 6 February 2021).

22. Lek, M.; Karczewski, K.J.; Minikel, E.V.; Samocha, K.E.; Banks, E.; Fennell, T.; O’Donnell-Luria, A.H.; Ware, J.S.; Hill, A.J.; Cummings, B.B.; et al. Analysis of protein-coding genetic variation in 60,706 humans. Nature 2016, 536, 285-291. [CrossRef]

23. Di Ronza, A.; Bajaj, L.; Sharma, J.; Sanagasetti, D.; Lotfi, P.; Adamski, C.J.; Collette, J.; Palmieri, M.; Amawi, A.; Popp, L.; et al. CLN8 is an endoplasmic reticulum cargo receptor that regulates lysosome biogenesis. Nat. Cell Biol. 2018, 20, $1370-1377$. [CrossRef] [PubMed]

24. Teixeira, F.R.; Manfiolli, A.O.; Vieira, N.A.; Medeiros, A.C.; Coelho, P.O.; Santiago Guimaraes, D.; Schechtman, D.; Gomes, M.D. FBXO25 regulates MAPK signaling pathway through inhibition of ERK1/2 phosphorylation. Arch. Biochem. Biophys. 2017, 621, 38-45. [CrossRef]

25. Watanabe, K.; Yokota, K.; Yoshida, K.; Matsumoto, A.; Iwamoto, S. Kbtbd11 contributes to adipocyte homeostasis through the activation of upstream stimulatory factor 1. Heliyon 2019, 5, e02777. [CrossRef] [PubMed]

26. Wang, X.; Jiang, H.; Zhou, W.; Zhang, Z.; Yang, Z.; Lu, Y.; Lu, B.; Wang, X.; Ding, Q.; Hu, R. Molecular cloning of a novel nuclear factor, TDRP1, in spermatogenic cells of testis and its relationship with spermatogenesis. Biochem. Biophys. Res. Commun. 2010, 394, 29-35. [CrossRef] 
27. Van der Ven, P.F.; Speel, E.J.; Albrechts, J.C.; Ramaekers, F.C.; Hopman, A.H.; Furst, D.O. Assignment of the human gene for endosarcomeric cytoskeletal M-protein (MYOM2) to 8p23.3. Genomics 1999, 55, 253-255. [CrossRef]

28. GTEx. Genotype-Tissue Expression. Available online: https://www.gtexportal.org/home/ (accessed on 17 March 2021).

29. DECIPHER. DatabasE of GenomiC VarIation and Phenotype in Humans Using Ensembl Resources. Available online: https: / / decipher.sanger.ac.uk/ (accessed on 6 February 2021).

30. Li, L.; Huang, L.; Luo, Y.; Huang, X.; Lin, S.; Fang, Q. Differing Microdeletion Sizes and Breakpoints in Chromosome 7q11.23 in Williams-Beuren Syndrome Detected by Chromosomal Microarray Analysis. Mol. Syndr. 2016, 6, 268-275. [CrossRef]

31. Bonati, M.T.; Castronovo, C.; Sironi, A.; Zimbalatti, D.; Bestetti, I.; Crippa, M.; Novelli, A.; Loddo, S.; Dentici, M.L.; Taylor, J.; et al. 9q34.3 microduplications lead to neurodevelopmental disorders through EHMT1 overexpression. Neurogenetics 2019, 20, 145-154. [CrossRef] [PubMed]

32. Venturin, M.; Gervasini, C.; Orzan, F.; Bentivegna, A.; Corrado, L.; Colapietro, P.; Friso, A.; Tenconi, R.; Upadhyaya, M.; Larizza, L.; et al. Evidence for non-homologous end joining and non-allelic homologous recombination in atypical NF1 microdeletions. Hum. Genet. 2004, 115, 69-80. [CrossRef] [PubMed]

33. Stankiewicz, T.R.; Linseman, D.A. Rho family GTPases: Key players in neuronal development, neuronal survival, and neurodegeneration. Front. Cell Neurosci. 2014, 8, 314. [CrossRef] [PubMed]

34. Chaya, T.; Shibata, S.; Tokuhara, Y.; Yamaguchi, W.; Matsumoto, H.; Kawahara, I.; Kogo, M.; Ohoka, Y.; Inagaki, S. Identification of a negative regulatory region for the exchange activity and characterization of T332I mutant of Rho guanine nucleotide exchange factor 10 (ARHGEF10). J. Biol. Chem. 2011, 286, 29511-29520. [CrossRef]

35. Verhoeven, K.; De Jonghe, P.; Van de Putte, T.; Nelis, E.; Zwijsen, A.; Verpoorten, N.; De Vriendt, E.; Jacobs, A.; Van Gerwen, V.; Francis, A.; et al. Slowed conduction and thin myelination of peripheral nerves associated with mutant rho Guanine-nucleotide exchange factor 10. Am. J. Hum. Genet. 2003, 73, 926-932. [CrossRef] [PubMed]

36. Jungerius, B.J.; Hoogendoorn, M.L.; Bakker, S.C.; Van't Slot, R.; Bardoel, A.F.; Ophoff, R.A.; Wijmenga, C.; Kahn, R.S.; Sinke, R.J. An association screen of myelin-related genes implicates the chromosome 22q11 PIK4CA gene in schizophrenia. Mol. Psychiatry 2008, 13, 1060-1068. [CrossRef]

37. Tabares-Seisdedos, R.; Rubenstein, J.L. Chromosome $8 \mathrm{p}$ as a potential hub for developmental neuropsychiatric disorders: Implications for schizophrenia, autism and cancer. Mol. Psychiatry 2009, 14, 563-589. [CrossRef]

38. Noto, Y.; Shiga, K.; Tsuji, Y.; Mizuta, I.; Higuchi, Y.; Hashiguchi, A.; Takashima, H.; Nakagawa, M.; Mizuno, T. Nerve ultrasound depicts peripheral nerve enlargement in patients with genetically distinct Charcot-Marie-Tooth disease. J. Neurol. Neurosurg. Psychiatry 2015, 86, 378-384. [CrossRef] [PubMed]

39. Boora, G.K.; Kulkarni, A.A.; Kanwar, R.; Beyerlein, P.; Qin, R.; Banck, M.S.; Ruddy, K.J.; Pleticha, J.; Lynch, C.A.; Behrens, R.J.; et al. Association of the Charcot-Marie-Tooth disease gene ARHGEF10 with paclitaxel induced peripheral neuropathy in NCCTG N08CA (Alliance). J. Neurol. Sci. 2015, 357, 35-40. [CrossRef] [PubMed]

40. SFARI Gene Database. Available online: https://gene.sfari.org/ (accessed on 6 February 2021).

41. Deneault, E.; White, S.H.; Rodrigues, D.C.; Ross, P.J.; Faheem, M.; Zaslavsky, K.; Wang, Z.; Alexandrova, R.; Pellecchia, G.; Wei, W.; et al. Complete Disruption of Autism-Susceptibility Genes by Gene Editing Predominantly Reduces Functional Connectivity of Isogenic Human Neurons. Stem Cell Rep. 2019, 12, 427-429. [CrossRef]

42. Gazzellone, M.J.; Zarrei, M.; Burton, C.L.; Walker, S.; Uddin, M.; Shaheen, S.M.; Coste, J.; Rajendram, R.; Schachter, R.J.; Colasanto, M.; et al. Uncovering obsessive-compulsive disorder risk genes in a pediatric cohort by high-resolution analysis of copy number variation. J. Neurodev. Disord. 2016, 8, 36. [CrossRef] [PubMed]

43. Xing, J.; Kimura, H.; Wang, C.; Ishizuka, K.; Kushima, I.; Arioka, Y.; Yoshimi, A.; Nakamura, Y.; Shiino, T.; Oya-Ito, T.; et al. Resequencing and Association Analysis of Six PSD-95-Related Genes as Possible Susceptibility Genes for Schizophrenia and Autism Spectrum Disorders. Sci. Rep. 2016, 6, 27491. [CrossRef]

44. Li, Y.; Wang, K.; Zhang, P.; Huang, J.; An, H.; Wang, N.; De Yang, F.; Wang, Z.; Tan, S.; Chen, S.; et al. Quantitative DNA Methylation Analysis of DLGAP2 Gene using Pyrosequencing in Schizophrenia with Tardive Dyskinesia: A Linear Mixed Model Approach. Sci. Rep. 2018, 8, 17466. [CrossRef] [PubMed]

45. Woodbury-Smith, M.; Zarrei, M.; Wei, J.; Thiruvahindrapuram, B.; O'Connor, I.; Paterson, A.D.; Yuen, R.K.C.; Dastan, J.; Stavropoulos, D.J.; Howe, J.L.; et al. Segregating patterns of copy number variations in extended autism spectrum disorder (ASD) pedigrees. Am. J. Med. Genet. B Neuropsychiatr. Genet. 2020, 183, 268-276. [CrossRef]

46. Wu, K.; Hanna, G.L.; Easter, P.; Kennedy, J.L.; Rosenberg, D.R.; Arnold, P.D. Glutamate system genes and brain volume alterations in pediatric obsessive-compulsive disorder: A preliminary study. Psychiatry Res. 2013, 211, 214-220. [CrossRef]

47. Curran, S.; Ahn, J.W.; Grayton, H.; Collier, D.A.; Ogilvie, C.M. NRXN1 deletions identified by array comparative genome hybridisation in a clinical case series-Further understanding of the relevance of NRXN1 to neurodevelopmental disorders. J. Mol. Psychiatry 2013, 1, 4. [CrossRef]

48. Hu, Z.; Xiao, X.; Zhang, Z.; Li, M. Genetic insights and neurobiological implications from NRXN1 in neuropsychiatric disorders. Mol. Psychiatry 2019, 24, 1400-1414. [CrossRef] [PubMed]

49. Castronovo, P.; Baccarin, M.; Ricciardello, A.; Picinelli, C.; Tomaiuolo, P.; Cucinotta, F.; Frittoli, M.; Lintas, C.; Sacco, R.; Persico, A.M. Phenotypic spectrum of NRXN1 mono- and bi-allelic deficiency: A systematic review. Clin. Genet. 2020, 97, 125-137. [CrossRef] 
50. LaConte, L.E.W.; Chavan, V.; Elias, A.F.; Hudson, C.; Schwanke, C.; Styren, K.; Shoof, J.; Kok, F.; Srivastava, S.; Mukherjee, K. Two microcephaly-associated novel missense mutations in CASK specifically disrupt the CASK-neurexin interaction. Hum. Genet. 2018, 137, 231-246. [CrossRef]

51. Pirozzi, F.; Nelson, B.; Mirzaa, G. From microcephaly to megalencephaly: Determinants of brain size. Dialogues Clin. Neurosci. 2018, 20, 267-282. [CrossRef]

52. Jean, F.; Stuart, A.; Tarailo-Graovac, M. Dissecting the Genetic and Etiological Causes of Primary Microcephaly. Front. Neurol. 2020, 11, 570830. [CrossRef] [PubMed]

53. Stracker, T.H.; Morrison, C.G.; Gergely, F. Molecular causes of primary microcephaly and related diseases: A report from the UNIA Workshop. Chromosoma 2020, 129, 115-120. [CrossRef] [PubMed]

54. Jiang-Xie, L.F.; Liao, H.M.; Chen, C.H.; Chen, Y.T.; Ho, S.Y.; Lu, D.H.; Lee, L.J.; Liou, H.H.; Fu, W.M.; Gau, S.S. Autism-associated gene Dlgap2 mutant mice demonstrate exacerbated aggressive behaviors and orbitofrontal cortex deficits. Mol. Autism 2014, 5, 32. [CrossRef] [PubMed]

55. Lu, D.H.; Liao, H.M.; Chen, C.H.; Tu, H.J.; Liou, H.C.; Gau, S.S.; Fu, W.M. Impairment of social behaviors in Arhgef10 knockout mice. Mol. Autism 2018, 9, 11. [CrossRef] [PubMed]

56. Horner, A.E.; Norris, R.H.; McLaren-Jones, R.; Alexander, L.; Komiyama, N.H.; Grant, S.G.N.; Nithianantharajah, J.; Kopanitsa, M.V. Learning and reaction times in mouse touchscreen tests are differentially impacted by mutations in genes encoding postsynaptic interacting proteins SYNGAP1, NLGN3, DLGAP1, DLGAP2 and SHANK2. Genes Brain Behav. 2020, e12723. [CrossRef]

57. STRING Database. Available online: https://string-db.org/ (accessed on 6 February 2021).

58. Verpelli, C.; Schmeisser, M.J.; Sala, C.; Boeckers, T.M. Scaffold proteins at the postsynaptic density. Adv. Exp. Med. Biol. 2012, 970, 29-61. [CrossRef]

59. Sala, C.; Vicidomini, C.; Bigi, I.; Mossa, A.; Verpelli, C. Shank synaptic scaffold proteins: Keys to understanding the pathogenesis of autism and other synaptic disorders. J. Neurochem. 2015, 135, 849-858. [CrossRef] [PubMed]

60. Soler, J.; Fananas, L.; Parellada, M.; Krebs, M.O.; Rouleau, G.A.; Fatjo-Vilas, M. Genetic variability in scaffolding proteins and risk for schizophrenia and autism-spectrum disorders: A systematic review. J. Psychiatry Neurosci. 2018, 43, 223-244. [CrossRef]

61. Taylor, S.C.; Ferri, S.L.; Grewal, M.; Smernoff, Z.; Bucan, M.; Weiner, J.A.; Abel, T.; Brodkin, E.S. The Role of Synaptic Cell Adhesion Molecules and Associated Scaffolding Proteins in Social Affiliative Behaviors. Biol. Psychiatry 2020, 88, $442-451$. [CrossRef]

62. Kaizuka, T.; Takumi, T. Postsynaptic density proteins and their involvement in neurodevelopmental disorders. J. Biochem. 2018, 163, 447-455. [CrossRef]

63. Park, E.; Na, M.; Choi, J.; Kim, S.; Lee, J.R.; Yoon, J.; Park, D.; Sheng, M.; Kim, E. The Shank family of postsynaptic density proteins interacts with and promotes synaptic accumulation of the beta PIX guanine nucleotide exchange factor for Rac1 and Cdc42. J. Biol. Chem. 2003, 278, 19220-19229. [CrossRef]

64. Sarowar, T.; Grabrucker, A.M. Actin-Dependent Alterations of Dendritic Spine Morphology in Shankopathies. Neural Plast. 2016, 2016, 8051861. [CrossRef] [PubMed]

65. Zeidan-Chulia, F.; Salmina, A.B.; Malinovskaya, N.A.; Noda, M.; Verkhratsky, A.; Moreira, J.C. The glial perspective of autism spectrum disorders. Neurosci. Biobehav. Rev. 2014, 38, 160-172. [CrossRef] [PubMed]

66. Bakos, J.; Bacova, Z.; Grant, S.G.; Castejon, A.M.; Ostatnikova, D. Are Molecules Involved in Neuritogenesis and Axon Guidance Related to Autism Pathogenesis? Neuromol. Med. 2015, 17, 297-304. [CrossRef] [PubMed]

67. Reichova, A.; Zatkova, M.; Bacova, Z.; Bakos, J. Abnormalities in interactions of Rho GTPases with scaffolding proteins contribute to neurodevelopmental disorders. J. Neurosci. Res. 2018, 96, 781-788. [CrossRef] [PubMed]

68. Cukier, H.N.; Dueker, N.D.; Slifer, S.H.; Lee, J.M.; Whitehead, P.L.; Lalanne, E.; Leyva, N.; Konidari, I.; Gentry, R.C.; Hulme, W.F.; et al. Exome sequencing of extended families with autism reveals genes shared across neurodevelopmental and neuropsychiatric disorders. Mol. Autism 2014, 5, 1. [CrossRef]

69. Liu, Y.; Fu, X.; Tang, Z.; Li, C.; Xu, Y.; Zhang, F.; Zhou, D.; Zhu, C. Altered expression of the CSMD1 gene in the peripheral blood of schizophrenia patients. BMC Psychiatry 2019, 19, 113. [CrossRef] [PubMed]

70. Crippa, M.; Malatesta, P.; Bonati, M.T.; Trapasso, F.; Fortunato, F.; Annesi, G.; Larizza, L.; Labate, A.; Finelli, P.; Perrotti, N.; et al. A familial t(4;8) translocation segregates with epilepsy and migraine with aura. Ann. Clin. Transl. Neurol. 2020, 7, 855-859. [CrossRef] [PubMed]

71. Harich, B.; Klein, M.; Ockeloen, C.W.; van der Voet, M.; Schimmel-Naber, M.; de Leeuw, N.; Schenck, A.; Franke, B. From man to fly-Convergent evidence links FBXO25 to ADHD and comorbid psychiatric phenotypes. J. Child Psychol. Psychiatry 2020, 61, 545-555. [CrossRef] [PubMed]

72. YUE Lab Computational and Functional Genomics/Epigenomics. Available online: http://3dgenome.fsm.northwestern.edu/ view.php (accessed on 27 February 2021).

73. Luedi, P.P.; Dietrich, F.S.; Weidman, J.R.; Bosko, J.M.; Jirtle, R.L.; Hartemink, A.J. Computational and experimental identification of novel human imprinted genes. Genome Res. 2007, 17, 1723-1730. [CrossRef] [PubMed] 